\title{
D. Howard Davies
}

Members of the British Cardiac Society have been saddened by the death of Howard Davies, consultant physician and cardiologist to the United Bristol Hospitals. He was for 21 years a member of the British Cardiac Society. Davies was born on 26 November I910, and was educated at Mill Hill School, Cambridge, and the Middlesex Hospital. He qualified with the Conjoint diploma in 1934, graduated M.B., B.Chir. in 1937, and took the M.R.C.P. the following year. He held appointments at Middlesex and Brompton Hospitals. He was appointed in 1947 consultant physician to the United Bristol Hospitals. He proceeded M.D. in 1949, and was elected F.R.C.P. in 1951.

The academic and professional career of Howard Davies has no doubt been formally chronicled elsewhere. I write now of the man as we, his colleagues and personal friends, knew him. My first encounter with Howard 'Taffy' to all his friends - was in 1937 when we were residents together at the Brompton Chest Hospital. Even then we all succumbed to the spell of his sincerity, his gentleness, and his immense sense of fun. These traits characterized the man throughout his career and were largely responsible for the deep affection he aroused in patients and colleagues alike.

Our happy association was renewed when Taffy was appointed as Cardiologist to the United Bristol Hospitals in 1946. Maturity had deepened his sincerity and clinical wisdom but had done nothing to dim the lustre of his irrepressible gaiety. Taffy loved people and was fascinated by their eccentricities and foibles. At professional gatherings he was always to be found at the centre of laughter. He could see something funny in even the most tedious and pompous of presentations. His Puckish delight in the ridiculous was contagious and could enliven any meeting.

Taffy's single-minded dedication to the well-being of his patients set a standard of professional integrity to which few of us could ever hope to aspire. As a surgical colleague one could disagree with his philosophy on the indications for treatment, but in retrospect he was usually proved to be right in his concern not to subject a patient to a dubious surgical operation, or what he regarded as an act of surgical unkindness, till he was convinced that it was necessary and worth while. As a clinician he left most of us with a deep sense of inadequacy. His kindness and wisdom were a source of great comfort also to the many personal friends and colleagues who instinctively turned to him for help when they, in turn, were afflicted.

Taffy was a modest man. His main contribution to the practice of medicine in Bristol was to create the Department of Cardiology at the United Bristol Hospitals and to promote the quiet efficiency with which this Department has flourished. For this he claimed no personal credit whatever. $\mathrm{He}$ instinctively chose the back row and used the word ' $I$ ' only under duress, a rare phenomenon in an age of professional arrogance, publicity, and television extravaganzas. Taffy would have none of this. He received no recognition during his life for his numerous, but unobtrusive, contributions to the medical life of his adopted University, but he neither expected nor asked for it.

Taffy was essentially a practising rather than a professing physician. He wrote but little because he was too busy doing good. But his deep sense of humility and lack of personal ambition also contributed to his reticence. He was a good clinical teacher because he taught good things and taught them well. He for ever impressed upon his students the value of compassion in the practice of medicine. He believed, taught, and proved that there is still a place for clinical examination in diagnosis. The interpretation of the welter of catheter figures and other laboratory data he happily left to his Registrar, but never allowed them to cloud his immense clinical wisdom.

Taffy loved the conviviality of the countryside and its people. Fast and beautiful cars were irresistible to him. A great fisherman and a true disciple of Isaac Walton, who at the conclusion of the 'Compleat Angler' admonishes us to 'study to be quiet'; even when he wasn't fishing Taffy believed in keeping quiet. 
He was blessed with a miraculous sense of humour and after losing the biggest salmon he ever hooked, when lesser men would weep, Taffy could sit down on the bank and laugh. This blessing served him in good stead in later years.

Medical politics and committee work were anathema to him because he believed passionately in the principle of minding one's own business and minding it well. But because his colleagues trusted him implicitly, he was reluctantly pressed into serving when matters of concern were at stake.

Envy and malice were unknown to him. He spoke ill of none, was rarely moved to anger, but often saddened by disloyalty, hypocrisy, or insincerity. It can be truly said that he hurt no one.

His latter years were marred by the anguish and searing loneliness of bereavement which he bore with a fortitude at which we all marvelled, but few could emulate. He became preoccupied with impending disaster and with a totally unjustified illusion of professional failure. At times he almost lost his zest for living but never his propensity for spontaneous laughter. But during these years of distress he cherished one enduring source of comfort, the loving companionship of his son and daughter, and his great pride in their many achievements.

Taffy was the epitome of what our American friends would so aptly call a 'lovely man' and will be remembered for many things. But to those who knew him most intimately it will always be his sincerity and humility; his generosity and gentleness; his barbless sense of humour; and in earlier years his irrepressible gaiety that will live longest. $\mathrm{He}$ set us all a shining example of how to live at peace with one's fellow men: decently, happily, and honourably, and finally to die with dignity.

RONALD BELSEY 